\title{
Potentiation by Granulocyte Macrophage Colony-stimulating Factor of Lipopolysaccharide Toxicity in Mice
}

\author{
G. Tiegs, J. Barsig, B. Matiba, S. Uhlig, and A. Wendel \\ Department of Biochemical Pharmacology, Faculty of Biology, University of Konstanz, 78434 Konstanz, Germany
}

\begin{abstract}
GM-CSF is known to prime leukocytes for inflammatory stimuli in vitro. The objective of this study was to investigate the role of GM-CSF in vivo in a systemic inflammatory reaction syndrome. The results demonstrate a potentiation of LPS toxicity by GM-CSF in a mortality model as well as in a septic liver failure model in mice.

Pretreatment of animals with $50 \mu \mathrm{g} / \mathrm{kg} \mathrm{GM-CSF}$ induced lethality within $24 \mathrm{~h}$ in mice challenged with a subtoxic dose of LPS while controls survived $>72 \mathrm{~h}$. A monoclonal anti-GMCSF antibody significantly protected against a lethal LPS dose. Serum GM-CSF was inducible by LPS and peaked at 2 h. GM-CSF pretreatment dramatically potentiated systemic TNF release and hepatotoxicity induced by a subtoxic dose of LPS in galactosamine-sensitized mice. Potentiation of LPS hepatotoxicity was possible until $\mathbf{3 0} \mathrm{min}$ after LPS challenge. Polyclonal anti-GM-CSF IgG protected against septic liver failure in this model and attenuated serum TNF concentrations. In vitro and ex vivo experiments revealed that after GM-CSF pretreatment LPS-induced IL-1 release from bone marrow or spleen cells was also enhanced. These findings suggest that GM-CSF represents an endogenous enhancer of LPS-induced organ injury, possibly by potentiating the release of proinflammatory cytokines such as TNF and IL-1. (J. Clin. Invest. 1994. 93:2616-2622.) Key words: GM-CSF • endotoxic shock • septic liver failure • tumor necrosis factor • interleukins
\end{abstract}

\section{Introduction}

Granulocyte macrophage colony-stimulating factor (GM$\mathrm{CSF}$ ) is a $23-\mathrm{kD}$ glycoprotein which stimulates the proliferation and differentiation of granulocytic and monocytic progenitor cells. Known cellular sources of this hemopoietic growth factor are macrophages, endothelial cells, fibroblasts, and Tlymphocytes (1). In addition to the effects on hemopoietic stem cells, GM-CSF exhibits proinflammatory properties on mature neutrophils, eosinophils, and macrophages, such as the priming effect on neutrophils for activation with a second stimulus (2-4), regulation of leukocyte adhesion (5-7), augmentation of antigen presentation (8), and enhancement or induction of cytokine production by neutrophils or macrophages

Address correspondence to A. Wendel, Biochemical Pharmacology, Faculty of Biology, University of Konstanz, PO Box 5560, M 667, D-78434 Konstanz, FRG.

Received for publication 28 June 1993 and in revised form 10 February 1994.

J. Clin. Invest.

(C) The American Society for Clinical Investigation, Inc.

0021-9738/94/06/2616/07 \$2.00

Volume 93, June 1994, 2616-2622
(9-12). The hemopoietic properties of GM-CSF prompted the treatment of cancer patients with this cytokine: GM-CSF was shown to accelerate granulocyte/monocyte recovery after chemotherapy or bone marrow transplantation (13-15).

Endotoxins (lipopolysaccharides, LPSs) are potent inducers of CSF production in vivo. The injection of LPS increases serum CSF levels in mice in the 2-9 $\mathrm{h}$ after administration (16). The LPS-inducible cytokines, TNF $\alpha$ or IL-1 stimulate GM-CSF production in macrophages, endothelial cells, and fibroblasts in vitro $(15,17,18)$. On the other hand, LPSinduced TNF and IL-1 production of monocytic cells was shown to be potentiated or induced by $\operatorname{GM}-\operatorname{CSF}(19,20)$.

We recently have demonstrated that granulocyte CSF (GCSF) reduced LPS-induced TNF release in vivo and ex vivo and thereby protected rodents against LPS shock and LPS hepatotoxicity (21). In that study, we also noticed that GM-CSF pretreatment significantly enhanced LPS-induced TNF release in vivo and increased mortality in galactosamine (GalN)-sensitized mice. We now report that GM-CSF potentiates LPS toxicity by stimulating the production of proinflammatory mediators such as TNF and IL-1. For these studies, we chose two different in vivo models of LPS-induced toxicity: In the first, a high dose of purified LPS was administered to induce septic shock with mortality as an endpoint. In the alternative model, i.e., endotoxin-induced liver injury in GalN-sensitized mice, serum transaminase release $8 \mathrm{~h}$ after challenge allowed the quantification of septic organ failure (22). As in the case of LPS-induced mortality (23), anti-mouse TNF antiserum also protected against LPS-induced hepatic failure in GalN-sensitized mice, emphasizing the common final pathway in either model (24). The biochemical basis of the GalN model is the fact that this aminosugar depletes intracellular uridine nucleotides selectively within the liver, leading to an inhibition of hepatic transcription (25), and thereby sensitizes mice towards LPS toxicity several thousand-fold (26). The organotropic toxicity of LPS mainly on the liver can be conveniently measured by determination of liver specific enzymes within the sera of the animals (22). There is ample evidence in the literature that the GalN model may resemble some important aspects of clinical reality: hepatic dysfunction develops frequently and early in sepsis (27) and continuously aggravates a vicious circle in the late phase of multiorgan failure, that consists of enhanced bacterial translocation due to loss of intestinal barrier function. This is potentiated by allowing gut-derived bacterial products to circulate because of impaired hepatic reticuloendothelial clearance (28).

The aim of this study was to investigate the role of GM-CSF in models of experimental sepsis and to gain insight into the modulation of shock by endogenous GM-CSF by studying the

1. Abbreviations used in this paper: ALT, alanine amino transferase; GalN, galactosamine; LIF, leukemia inhibitory factor. 
relationship between GM-CSF and mediators of LPS toxicity such as TNF and IL-1.

\section{Methods}

Animals. Ten-wk-old male NMRI albino mice were purchased from the Zentralinstitut Hannover (Hannover, Germany). 6-8-wk-old BALB/c mice of either sex were obtained from the animal house of the University of Konstanz (Konstanz, Germany). They were kept at least 1 wk under controlled conditions $\left(24^{\circ} \mathrm{C}, 55 \%\right.$ humidity, $12 \mathrm{~h}$ day-night rhythm, diet of Altromin C 1310) before the experiments.

Materials. Salmonella abortus equi endotoxin was from Sebak (Aidenbach, Germany), D-galactosamine $\mathrm{HCl}$ from C. Roth Chemicals (Karlsruhe, Germany). Recombinant murine $\mathrm{TNF} \alpha$ was a generous gift from Dr. G. R. Adolf (Bender Co., Vienna, Austria). Recombinant yeast-derived murine GM$\mathrm{CSF}\left(1 \times 10^{7} \mathrm{U} / \mathrm{mg}\right)$ and polyclonal rabbit anti-mouse GMCSF antibody (IgG) were kindly provided by Dr. F. R. Seiler (Behring-Werke, Marburg, Germany). Specificity of polyclonal IgG was checked by Western blot analysis, using murine leukemia inhibitory factor (LIF), IL-1 $\alpha$ (both from Genzyme Corp., Cambridge, MA), IL-6 (Endogen, Inc., Boston, MA), IFN $\gamma$ (Boehringer Mannheim, Mannheim, Germany), and $\mathrm{TNF} \alpha$ in comparison with GM-CSF. The endotoxin content of GM-CSF was less than $1 \mathrm{EU} / \mathrm{mg}$ according to the supplier's information. A monospecific anti-mouse GM-CSF mAb (1 $\mathrm{mg} / \mathrm{ml}$, Isotype: $\mathrm{IgG}_{1}$ kappa, clone: MP1-31G6), that neutralizes GM-CSF bioactivity was purchased from Endogen, Inc. Recombinant murine IL- 6 and IL-6 coating and detecting antibodies for performing an IL-6 ELISA were from Pharmingen, (San Diego, CA). For injection, all materials were dissolved in pyrogen-free PBS. Cell culture media were purchased from Biochrom (Berlin, Germany). Bacto-agar was from Difco (Detroit, MI).

In vivo experiments. Recombinant murine GM-CSF was dissolved in $0.1 \%$ HSA (Biotest $20 \%$, clinical grade; Biotest Pharma, Dreieich, Germany)/PBS and injected i.v. in a dose of $50 \mu \mathrm{g} / \mathrm{kg} .1 \mathrm{mg}$ of polyclonal anti-mouse GM-CSF antibody or rabbit pre-immuneserum and $100 \mu \mathrm{g}$ of monoclonal antimouse GM-CSF antibody per animal were injected i.v. $10 \mathrm{~min}$ before challenge. For inducing septic liver failure, male NMRI mice were challenged by $700 \mathrm{mg} / \mathrm{kg} \mathrm{GalN}$ i.p. together with the indicated concentrations of LPS. Alternatively, they received recombinant murine TNF $\alpha$ i.v. $1 \mathrm{~h}$ after GalN instead of LPS. Blood for determination of TNF was obtained from the retroorbital plexus or from the tail vein $90 \mathrm{~min}$ after LPS administration. For determination of alanine amino transferase (ALT) in serum, as a measure of liver injury $8 \mathrm{~h}$ after challenge, blood was withdrawn by heart puncture after cervical dislocation. Endotoxin shock experiments were performed by injecting 3-5 $\mathrm{mg} / \mathrm{kg}$ LPS i.p. in BALB/c mice; survival was monitored until $72 \mathrm{~h}$ after challenge. In these experiments, blood samples for assessment of cytokines were obtained from the tail vein.

In vitro TNF and IL-1 determination in bone marrow cell cultures. Bone marrow cells of NMRI mice were isolated according to Metcalf (see reference 31 ). $5 \times 10^{5}$ cells per $0.5 \mathrm{ml}$ RPMI $1640,100 \mathrm{U} / \mathrm{ml}$ penicillin, $100 \mathrm{U} / \mathrm{ml}$ streptomycin, 2 $\mathrm{mM}$ L-glutamine, $10 \%$ heat-inactivated fetal calf serum (Biochrom) were incubated for the indicated time intervals at $37^{\circ} \mathrm{C}, 5 \% \mathrm{CO}_{2}$. Supernatants were stored at $-70^{\circ} \mathrm{C}$.

Ex vivo IL-1 determination in spleen cell supernatants. For determination of IL-1 production ex vivo, spleens of NMRI mice were removed $1 \mathrm{~h}$ after LPS administration in vivo. Spleen cells were isolated by spreading the tissue through gauze into $5 \mathrm{ml} \mathrm{RPMI} 1640,100 \mathrm{U} / \mathrm{ml}$ penicillin, $100 \mathrm{U} / \mathrm{ml}$ streptomycin, $2 \mathrm{mM} \mathrm{L}$-glutamine (Biochrom) at $37^{\circ} \mathrm{C} .3 \times 10^{6}$ spleen leukocytes per $\mathrm{ml}$ were incubated for $20 \mathrm{~h}$ at $37^{\circ} \mathrm{C}, 5 \% \mathrm{CO}_{2}$. Cells were centrifugated at $1,000 \mathrm{~g}$ for $5 \mathrm{~min}$ at $4^{\circ} \mathrm{C}$. Supernatants were stored at $-70^{\circ} \mathrm{C}$.

IL-1 assay. IL-1 was determined according to reference Hopkins and Humphreys (29) using the non-adherent Thelper cell line D10N (provided by Dr. S. J. Hopkins, University of Manchester, UK) in a proliferation assay. Cells were incubated at a cell density of $2 \times 10^{4}$ cells per $200 \mu \mathrm{l}$ at $37^{\circ} \mathrm{C}$ and $5 \% \mathrm{CO}_{2}$ with serially diluted test samples in 96-well flat bottom plates. IL-1-dependent proliferation of D10N cells was determined $72 \mathrm{~h}$ later using the dye MTT tetrazolium $(5 \mathrm{mg} /$ $\mathrm{ml} ; 1 / 10$ [vol/vol]; Sigma Chemical Co., St. Louis, Mo.). After incubation for $4 \mathrm{~h}$ at $37^{\circ} \mathrm{C}, 5 \% \mathrm{CO}_{2}$, cells were lysed by addition of $50 \mu \mathrm{l}$ of $20 \% \mathrm{SDS}$ wt $/ \mathrm{vol}$ in $0.02 \mathrm{~N} \mathrm{HCl}$. Plates were read $18 \mathrm{~h}$ later on a SLT EAR 400 microplate reader, with a test wavelength of $560 \mathrm{~nm}$ and a reference wavelength of $690 \mathrm{~nm}$. The titer of IL-1 was calculated in units per ml; one unit is defined as the reciprocal of the dilution providing $50 \%$ of maximal proliferation. IL-1 is expressed in picograms (pg) per $\mathrm{ml}$, using an internal recombinant murine IL-1 $\beta$ standard. The specificity of the proliferation for IL-1 was checked with a monoclonal goat anti-mouse IL- $1 \beta$ antibody (IgG; Hermann Biermann GmbH, Bad Nauheim, Germany) and a polyclonal goat anti-mouse IL-1 $\alpha$ specific antiserum (provided by Dr. H.-U. Beuscher, University of Erlangen, Germany).

TNF assay. TNF in serum of mice was determined essentially as described by Espevik and Nissen-Meyer (30). In brief, Fibrosarcoma cells (WEHI 164 clone 13, provided by Dr. T. Espevik, University of Trondheim, Norway) at a concentration of $2 \times 10^{4}$ cells per $200 \mu$ l were incubated with serially diluted test samples in 96-well flat-bottom microtiter plates and incubated for $18 \mathrm{~h}$ at $37^{\circ} \mathrm{C}$ and $5 \% \mathrm{CO}_{2}$. Then, 3-[4,5-dimethylthiazol-2-yl]-2,5-diphenyltetrazolium bromide (MTT) $(5 \mathrm{mg} / \mathrm{ml} ; 1 / 10$ [ $\mathrm{vol} / \mathrm{vol}])$ was added for determination of cytotoxicity. After incubation for $4 \mathrm{~h}$ at $37^{\circ} \mathrm{C}$ in the presence of $5 \% \mathrm{CO}_{2}$, the dye was removed and cells were lysed by the addition of $100 \mu \mathrm{l}$ of isopropanol/5\% formic acid. Plates were read as described in the IL-1 assay. TNF is expressed in $\mathrm{pg} / \mathrm{ml}$, calculated with the use of a recombinant murine TNF $\alpha$ standard.

GM-CSF ELISA. GM-CSF ELISA kits were purchased from Endogen Inc. Control mouse serum (30\% in supplied standard diluent ) was used as blocking buffer and for preparation of standard curves. The assay did not cross-react with murine TNF according to the manufacturer's informations. In our hands, there was also no cross-reactivity with murine IL-1 $\alpha$ or IL-1 $\beta$.

IL-6 ELISA. IL-6 ELISA was performed using Pharmingen antibodies according to the manufacturer's instructions.

Soft-agar assay for CSFs. Murine bone marrow cells were isolated as described elsewhere (31). Bacto-agar was dissolved in $\mathrm{H}_{2} \mathrm{O}$ at $95^{\circ} \mathrm{C}$ in a concentration of $3 \%(\mathrm{w} / \mathrm{vol})$. The agar solution was diluted with IMDM medium at $37^{\circ} \mathrm{C}$ to a final concentration of $0.3 \% .2 \times 10^{5}$ bone marrow cells per ml agar were added to $200 \mu$ l test sample in a six-well cell culture plate. The final serum concentration in the assay was $1 \%$. After congealing at room temperature, the plates were incubated at $37^{\circ} \mathrm{C}, 5 \% \mathrm{CO}_{2}$ for 5 to $6 \mathrm{~d}$. All colonies with $\geq 50$ cells were counted. GM-CSF colonies were identified by their typical mor- 

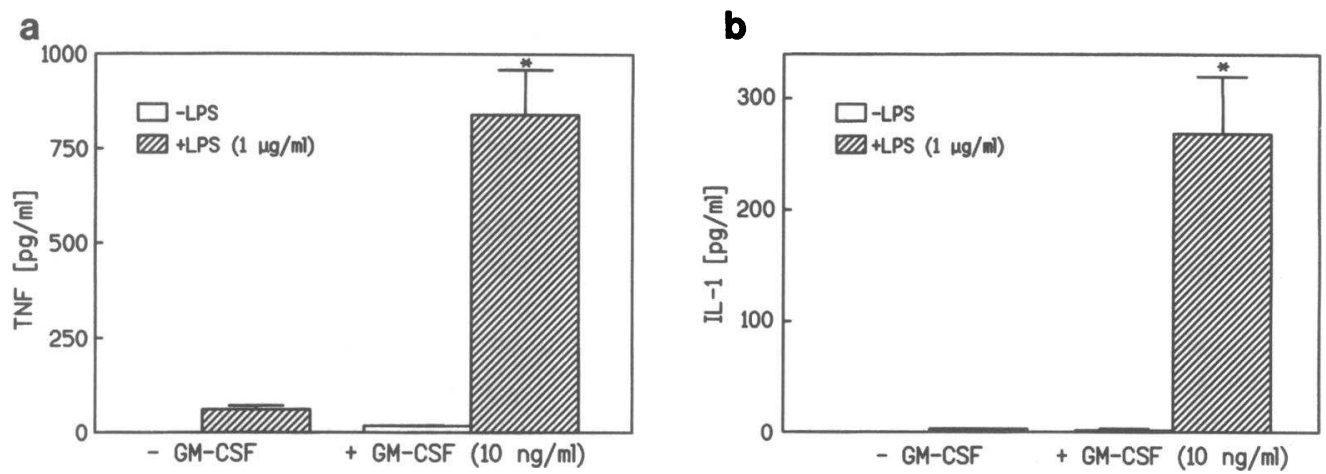

Figure 1. Potentiation by GMCSF of LPS-induced TNF release $(a)$ and IL-1 release $(b)$ in vitro. Murine bone marrow cells $\left(5 \times 10^{5}\right.$ per $\left.0.5 \mathrm{ml}\right)$ were incubated for $6 \mathrm{~h}$ with or without $1 \mu \mathrm{g} / \mathrm{ml} \mathrm{LPS}$ and $10 \mathrm{ng} / \mathrm{ml}$ GM-CSF $2 \mathrm{~h}$ before addition of LPS. IL-1 and TNF activities were determined in the supernatants by bioassay. Mean values $\pm \mathrm{SEM} ; n=3 .{ }^{*} P<0.05$ vs. LPS alone. phological shape and by the lack of growth in presence of an anti-mouse GM-CSF antibody. TNF, IL-1, or LPS did not interfere with this test.

Enzyme assay procedure. ALT activities in plasma were determined in an automated enzyme activity assay based on that described previously (22).

Statistics. Data are given as mean values \pm standard errors of the mean ( $\overline{\mathrm{x}} \pm \mathrm{SEM})$. For analysis, data were subjected to one-sided nonparametric multiple comparison of the control against all other groups (32). Survival times were analyzed by the LIFETEST procedure (generalized Wilcoxon Test) of the $\mathrm{SAS}^{\circledR}$ software package, release 6.08 (SAS Institute Inc., Cary, NC). $P \leq 0.05$ was always considered significant.

\section{Results}

\section{Priming by GM-CSF}

In vitro studies. GM-CSF was shown to prime monocytes in vitro for endotoxin-induced TNF-dependent cytotoxicity (19) and for enhanced IL-1 release upon LPS stimulation (20). To study this priming effect of GM-CSF towards LPS in vivo in mice, we first evaluated GM-CSF priming towards cytokine producing murine cells in vitro. Preincubation with GM-CSF of freshly prepared bone marrow cells enhanced LPS-induced TNF release by a factor of 14 (Fig. $1 a$ ). In the same cell culture supernatants we also found increased levels of IL-1 (Fig. $1 b$ ). Using specific neutralizing antibodies, $60 \%$ of the LPS-induc-

Table I. Aggravation of Septic Liver Failure by GM-CSF Treatment and Enhancement of Serum TNF Levels in GalNsensitized Mice Challenged with Subtoxic Doses of LPS

\begin{tabular}{lccc}
\hline \multicolumn{1}{c}{ Challenge } & ALT $(\mathrm{U} / \mathrm{l})$ & TNF $(\mathrm{pg} / \mathrm{ml})$ & $n$ \\
\hline None & $40 \pm 10$ & $\leq 50$ & 6 \\
GalN/LPS $(5 \mu \mathrm{g} / \mathrm{kg})$ & $2,170 \pm 915^{*}$ & $2,340 \pm 851^{*}$ & 6 \\
GalN/LPS $(0.2 \mu \mathrm{g} / \mathrm{kg})$ & $316 \pm 170$ & $180 \pm 42$ & 6 \\
GalN/LPS $(0.2 \mu \mathrm{g} / \mathrm{kg})$ & & & \\
$\quad+$ GM-CSF & $7,120 \pm 2,260^{*}$ & $21,180 \pm 7,950^{*}$ & 6 \\
GalN + GM-CSF & $150 \pm 37$ & $\leq 50$ & 6 \\
& & &
\end{tabular}

GM-CSF was given in a dose of $50 \mu \mathrm{g} / \mathrm{kg}$ i.v. $30 \mathrm{~min}$ after GalN (700 $\mathrm{mg} / \mathrm{kg}$, i.p.) plus LPS $(0.2 \mu \mathrm{g} / \mathrm{kg}$, i.p.). ALT was measured $8 \mathrm{~h}$ after GalN/LPS, TNF was determined $90 \mathrm{~min}$ after GalN/LPS administration. Mean values \pm SEM. ${ }^{*} P \leq 0.05$ vs. none. ible IL-1-dependent proliferation activity in the IL-1 assay was identified as IL- $1 \beta$ and $40 \%$ as IL- $1 \alpha$.

In vivo studies. Next we examined whether priming for enhanced cytokine release takes place in vivo and which consequences arise from this phenomenon in endotoxic shock models in animals. In a lethality model of LPS toxicity, all BALB/c mice pretreated with $50 \mu \mathrm{g} / \mathrm{kg}$ GM-CSF before subtoxic LPS challenge $(3 \mathrm{mg} / \mathrm{kg})$ died within $24 \mathrm{~h}$, whereas all animals which had received LPS alone, survived $>72 \mathrm{~h}(n=6)$. Serum TNF levels $1.5 \mathrm{~h}$ after challenge were significantly enhanced by GM-CSF pretreatment compared to LPS challenge alone $(17.6 \pm 3.3 \mathrm{ng} / \mathrm{ml}$ vs. $0.8 \pm 0.1 \mathrm{ng} / \mathrm{ml} ; P<0.05)$. In a parallel experiment, IL- 6 concentrations were also significantly enhanced at the same time point from $31.9 \pm 1.4 \mathrm{ng} / \mathrm{ml}$ in the control group to $105.1 \pm 3.7 \mathrm{ng} / \mathrm{ml}$ in the pretreated group $(P$ $<0.05 ; n=3)$. GM-CSF treatment alone did not induce detectable amounts of TNF or IL-6.

To further investigate the role of GM-CSF in modulating LPS toxicity, we used an alternative in vivo model of septic shock, i.e., LPS-induced liver failure in GalN-sensitized mice. NMRI mice treated simultaneously with $700 \mathrm{mg} / \mathrm{kg} \mathrm{GalN}$ and $5 \mu \mathrm{g} / \mathrm{kg}$ LPS i.p. developed severe liver injury within $8 \mathrm{~h}$ as shown by increased activities of the liver specific enzyme alanine aminotransferase (ALT) in the sera of the animals. Liver injury was preceded by the release of TNF into the circulation with maximal serum TNF concentrations 90 min after challenge (first group in Table I and reference 33). Animals chal-

Table II. Time Dependence of GM-CSF Pretreatment with Respect to Potentiation of Hepatotoxicity Induced by LPS in GalN-sensitized Mice

\begin{tabular}{lcccc}
\hline Pretreatment & $\begin{array}{c}\text { Time of } \\
\text { administration }\end{array}$ & ALT & TNF & $n$ \\
\hline & $h$ & $U / l$ & $p g / m l$ & \\
None & & $60 \pm 40$ & $50 \pm 40$ & 6 \\
GM-CSF & -18 & $754 \pm 574$ & $325 \pm 290$ & 6 \\
GM-CSF & -12 & $344 \pm 164$ & $525 \pm 260$ & 6 \\
GM-CSF & -0.5 & $2,260 \pm 1,062^{*}$ & $12,522 \pm 3,423^{*}$ & 5 \\
\hline
\end{tabular}

GM-CSF was given in a dose of $50 \mu \mathrm{g} / \mathrm{kg}$ i.v. prior to GalN $(700 \mathrm{mg} /$ $\mathrm{kg}$, i.p.) plus LPS $(0.2 \mu \mathrm{g} / \mathrm{kg}$, i.p.) at the time points indicated. ALT was measured $8 \mathrm{~h}$ after GalN/LPS, TNF was determined $90 \mathrm{~min}$ after GalN/LPS administration. Mean values \pm SEM. ${ }^{*} P \leq 0.05$ vs. GalN/LPS alone. 
lenged with GalN and subtoxic amounts of LPS $(0.2 \mu \mathrm{g} / \mathrm{kg}$ LPS i.p.), developed little liver damage. However, in those animals pretreatment with GM-CSF primed for LPS-induced systemic TNF release and organ injury (Table II). LPS-induced serum TNF and ALT concentrations were slightly increased when GM-CSF was given as early as 18 and $12 \mathrm{~h}$ before challenge and were significantly enhanced when it was given 30 min before LPS treatment ( Table II). GM-CSF potentiated the hepatic lesion even when administered to GalN-sensitized mice $30 \mathrm{~min}$ after a subtoxic LPS-dose, i.e. $0.2 \mu \mathrm{g} / \mathrm{kg}$ ( Table I, groups 3 and 4 ). In addition to potentiating liver injury, this treatment also augmented LPS-induced TNF production. Administration of GM-CSF alone, i.e., without LPS, to GalN-sensitized mice failed to induce detectable amounts of TNF or liver damage (Table I, group 5).

Since we were not able to measure IL-1 in vivo, because mouse serum was toxic to the D10N T cell line used in our bioassay, we chose an ex vivo setting for determination of the cytokine. Applying this method, we could observe enhanced IL-1 release from spleen cell cultures of GM-CSF pretreated NMRI mice, that were challenged in vivo with GalN plus subtoxic amounts of LPS (Fig. 2). All the LPS-inducible spleen cell derived IL-1 turned out to be IL- $1 \alpha$, since it was blocked by a polyclonal anti-mouse IL- $1 \alpha$ specific antiserum.

\section{Circulating GM-CSF in LPS treated mice}

The observation that GM-CSF not only potentiated LPS-induced TNF production when given before LPS, but also when given $30 \mathrm{~min}$ after LPS, prompted us to investigate the role of endogenously produced GM-CSF following LPS administration.

Fig. 3 shows the time course of GM-CSF and TNF induced by $3 \mathrm{mg} / \mathrm{kg}$ LPS. $1 \mathrm{~h}$ after LPS administration, considerable amounts of GM-CSF were found in the sera of the animals. Maximal GM-CSF concentrations were reached $2 \mathrm{~h}$ after injection of LPS. The experiment in Fig. 3 demonstrates further that the initial time courses of GM-CSF and TNF release are very similar. However, while TNF disappears very rapidly from the circulation, GM-CSF concentrations decline more slowly. In the other model used, i.e., GalN/LPS-induced liver damage, no GM-CSF was detectable in sera of these animals by ELISA. Because only small amounts of LPS are required in the GalN/

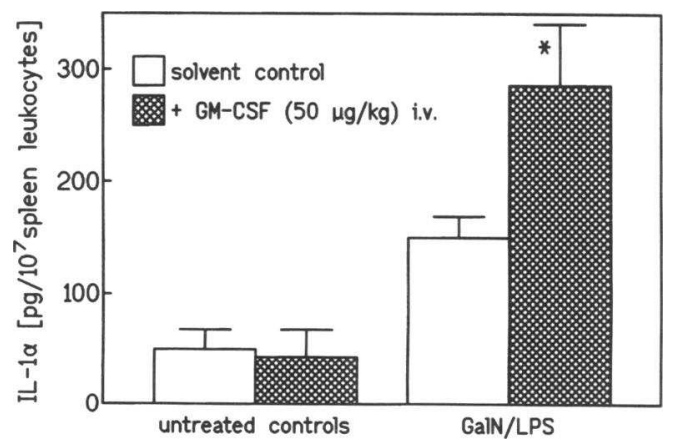

Figure 2. Potentiation by GM-CSF of LPS-induced IL-1 release ex vivo. Mice were pretreated intravenously with $50 \mu \mathrm{g} / \mathrm{kg} \mathrm{GM}-\mathrm{CSF}$ or solvent $(0.1 \% \mathrm{HSA} / \mathrm{PBS}) 30 \mathrm{~min}$ before administration of $0.2 \mu \mathrm{g} / \mathrm{kg}$ LPS plus $700 \mathrm{mg} / \mathrm{kg}$ GalN i.p. $1 \mathrm{~h}$ later, spleens were removed, spleen cells were isolated, and $3 \times 10^{6}$ spleen leukocytes per $\mathrm{ml}$ were incubated for $20 \mathrm{~h}$. IL-1 was determined in the supernatants by bioassay. Mean values \pm SEM; $n=6 .{ }^{*} P<0.05$ vs. GalN/LPS alone.

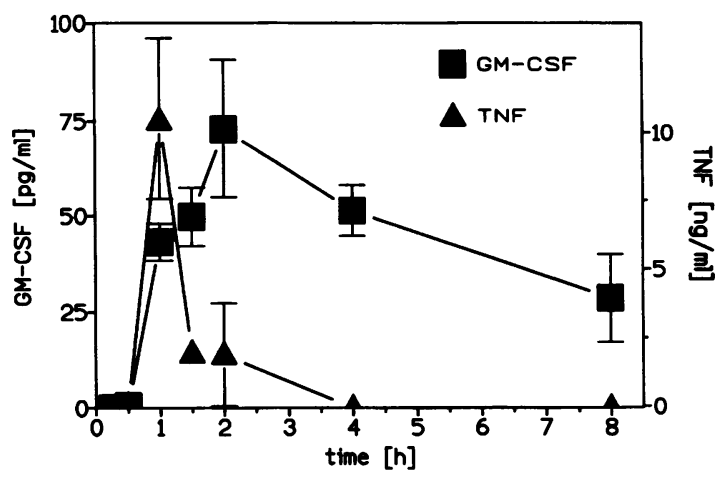

Figure 3. Time course of serum GM-CSF and TNF concentrations in mice after LPS treatment. Mice were challenged by i.p. injection of $3 \mathrm{mg} / \mathrm{kg}$ LPS. GM-CSF was assessed by ELISA and TNF by bioassay. In samples of vehicle injected mice neither GM-CSF nor TNF were detectable. Mean values $\pm \mathrm{SEM} ; n=3$.

LPS model compared to LPS induced shock, serum GM-CSF levels might have been below the detection limit of the assay. An alternative method of determining colony stimulating factors is by the soft agar assay (31). With this method and by using GM-CSF antibodies to check specificity, a similar time course of LPS-induced serum GM-CSF concentrations was found also in GalN/LPS-treated animals (data not shown). As shown in Table III, $20 \%$ of the total colony forming activity of serum measured $2 \mathrm{~h}$ after GalN/LPS administration to mice was due to GM-CSF.

\section{Neutralization of GM-CSF bioactivity in vivo}

Neutralization of GM-CSF in experimental endotoxic shock. To study the importance of endogenously produced GM-CSF for the pathogenesis of LPS-induced mortality, we administered a neutralizing monoclonal anti-mouse GM-CSF antibody ( $100 \mu \mathrm{g} /$ mouse) shortly before lethal LPS injection. This treatment significantly reduced mortality in the antibody treated group (Fig. 4). The mean TNF levels in the passively immunized group were $50 \%$ of the not pretreated group. However, due to great interindividual variability the differences between the groups were not significant $(9.41 \pm 5.00 \mathrm{ng} / \mathrm{ml}$ vs. $18.98 \pm 9.59 \mathrm{ng} / \mathrm{ml})$. In addition, the IL-6 levels in the serum samples of the animals, that had received the anti-GM-CSF antibody, were reduced to $26.94 \pm 7.15 \mathrm{ng} / \mathrm{ml}$ vs. $46.15 \pm 3.85$ $\mathrm{ng} / \mathrm{ml}$ in the control group $(P<0.05)$. It should be mentioned that according to the manufacturer's informations, the antiGM-CSF antibody does not crossreact with murine IL-6.

Neutralization of GM-CSF in GalN-sensitized mice. Pretreatment of NMRI mice with a polyclonal rabbit anti-mouse GM-CSF antibody completely suppressed GM-CSF colony forming activity, significantly reduced serum TNF levels, and protected against liver injury (Table III). Rabbit pre-immune serum was without any effect (data not shown).

Further experiments examined the question whether endogenous GM-CSF aggravated organ injury once TNF $\alpha$ is in the circulation. We therefore pretreated GalN-sensitized mice with the polyclonal GM-CSF antibody and challenged them by intravenous injection of $15 \mu \mathrm{g} / \mathrm{kg} \mathrm{TNF} \alpha$ instead of LPS. As shown in Table III, the antibody pretreatment failed to protect against septic liver failure induced by TNF $\alpha$. Also, GM-CSF pretreatment had no significant influence on liver injury induced with a lower dose of $3 \mu \mathrm{g} / \mathrm{kg}$ TNF $\alpha$ in GalN-sensitized 
Table III. Protection by Anti-Mouse GM-CSF Antibodies against LPS but not against TNF-induced Hepatotoxicity in GalN-sensitized Mice

\begin{tabular}{llcccc}
\hline Pretreatment & Challenge & ALT* & TNF $^{*}$ & CSF $^{5}$ & GM-CSF" $^{*}$ \\
\hline & & $U / l$ & $p g / m l$ & $\leq 1$ \\
None & None & $40 \pm 4$ & $\leq 50$ & $\leq 1$ & $36 \pm 3$ \\
None & GalN/LPS & $4,915 \pm 1,308$ & $9,810 \pm 4,065$ & $39 \pm 2$ & $\leq 1$ \\
Anti GM-CSF & GalN/LPS & $236 \pm 49^{* *}$ & $974 \pm 473^{* *}$ & \\
None & GalN/TNF $\alpha$ & $8,940 \pm 3,240$ & & \\
Anti GM-CSF & GalN/TNF $\alpha$ & $5,690 \pm 1,550$ & &
\end{tabular}

$* 8 \mathrm{~h}$ after challenge $(n=10)$. $\$ 90 \mathrm{~min}$ after challenge $(n=5) .{ }^{\S}$ Colonies $2 \mathrm{~h}$ after challenge $(n=5)$. " Colonies lacking growth in the presence of polyclonal anti-mouse GM-CSF antibodies (IgG) $(n=5)$. 'Polyclonal anti-mouse GM-CSF antibody (IgG): $1 \mathrm{mg}$ per mouse $10 \mathrm{~min}$ before challenge: $700 \mathrm{mg} / \mathrm{kg}$ GalN plus $5 \mu \mathrm{g} / \mathrm{kg}$ LPS i.p. or $700 \mathrm{mg} / \mathrm{kg}$ GalN i.p. and $15 \mu \mathrm{g} / \mathrm{kg}$ TNF $\alpha$ i.v. $15 \mathrm{~min}$ after GalN. Mean values $\pm S E M$. ** $P \leq 0.05$ vs. GalN/LPS alone.

mice (GalN/TNF $\alpha:$ ALT: 1,440 \pm 664 [U/1]; $50 \mu \mathrm{g} / \mathrm{kg} \mathrm{GM-}$ CSF i.v. 30 min before GalN/TNF $\alpha$ : ALT: 1,670 906 [U/1]; $50 \mu \mathrm{g} / \mathrm{kg}$ GM-CSF i.v. $5 \mathrm{~min}$ before GalN/TNF $\alpha$ : ALT: $1,460 \pm 891[\mathrm{U} / 1] ; 50 \mu \mathrm{g} / \mathrm{kg}$ GM-CSF i.v. $1 \mathrm{~h}$ after GalN/ TNF $\alpha$ : ALT: $2,530 \pm 1,438[\mathrm{U} / 1])$.

\section{Role of GM-CSF in the development of early phase tolerance towards LPS}

LPS-induced early phase tolerance is known to be independent of antibody production and is induced by administration of subtoxic amounts of LPS as early as $1 \mathrm{~h}$ before a toxic challenge. We explored the possibility that tolerance is due to inhibition of the release of the enhancer GM-CSF. The data in Table IV show that in tolerant mice, not developing septic liver failure upon challenge, the release of CSFs as well as of GM-CSF was enhanced rather than reduced, whereas TNF levels were partially suppressed. Thus, inhibition of CSFs is unlikely to account for a mechanism of tolerance.

\section{Discussion}

It has become increasingly evident that GM-CSF in addition to being an important hematopoietic growth factor is also a modulator of granulocyte and macrophage functions. In vitro experiments have shown that various leukocyte functions are subject to priming by GM-CSF. However, only little information exists about the contribution of priming by GM-CSF to processes in the whole organism such as inflammation. It was the aim of this study to investigate the role of GM-CSF in endotoxinbased models of inflammation and organ failure, i.e., LPS-induced shock and LPS-induced liver failure in GalN-sensitized mice, a quantifiable model for studying the basic pathophysiol- ogy of septic shock $(21,22)$. In terms of experimental reproducibility in future experiments, it is noteworthy that the extent of GM-CSF potentiation of TNF release and LPS toxicity showed a variability which was dependent on the actual LPS dose-response curve in the individual experiment.

The priming by GM-CSF of granulocytes and of cells derived from the monocyte lineage has been studied repeatedly. It is known that pretreatment of monocytes with GM-CSF primes these cells for endotoxin-induced TNF production (19). Like LPS shock models, the GalN/LPS-induced hepatitis is an endotoxic model where the pivotal role of TNF for inducing hepatotoxicity is documented $(24,34,35)$. The present study demonstrates that GM-CSF is able to prime for LPSinduced TNF-production in vivo and that this priming may, in fact, have detrimental consequences for the whole organism. Beyond this statement, the protection against TNF-release and organ injury by anti-GM-CSF antibodies (see Table III and Results) suggests that GM-CSF participates endogenously in the response to LPS. The fact that no complete protection was achieved with the antibody is either a matter of dosage and titer, or it suggests that endogenous GM-CSF plays an auxiliary role as a modulator of the LPS-induced mediator production. Since LPS induced both, TNF and GM-CSF, the latter cytokine may act as an amplifier of LPS-induced TNF-production (Table III).

Large discrepancies in the detectable amounts of different circulating cytokines after LPS challenge were found, i.e., TNF peak concentrations of $11 \mathrm{ng} / \mathrm{ml}$ compared with $125 \mathrm{pg} / \mathrm{ml}$ serum GM-CSF (Fig. 3). This suggests that small amounts of GM-CSF may be able to enhance the LPS-induced TNF release, but we cannot rule out the existence of high local concentrations of GM-CSF. The amounts of GM-CSF detected in GalN/LPS treated mice $2 \mathrm{~h}$ after treatment were very low, i.e.,

Table IV. Independence of LPS-induced Early Phase Tolerance and CSF- or GM-CSF-Release

\begin{tabular}{|c|c|c|c|c|c|c|}
\hline Pretreatment & Challenge & $\operatorname{ALT}[U / /]^{*}$ & $\mathrm{CSF}^{*}$ & $\mathrm{GM}^{-\mathrm{CSF}^{5}}$ & TNF" & $n$ \\
\hline None & GalN/LPS & $1,240 \pm 280$ & $50 \pm 3$ & $10 \pm 2$ & $3160 \pm 860$ & 6 \\
\hline LPS $(0.2 \mu \mathrm{g} / \mathrm{kg})$ & GalN/LPS & $60 \pm 20^{\prime}$ & $65 \pm 2^{\prime}$ & $20 \pm 1^{\prime}$ & $870 \pm 410^{\prime}$ & 5 \\
\hline LPS $(0.2 \mu \mathrm{g} / \mathrm{kg})$ & None & $70 \pm 30$ & $6 \pm 1$ & $\leq 1$ & $\leq 50$ & 3 \\
\hline
\end{tabular}

* $8 \mathrm{~h}$ after challenge. ${ }^{\ddagger}$ Colonies $2 \mathrm{~h}$ after challenge. ${ }^{8}$ Colonies lacking growth in the presence of polyclonal anti-mouse GM-CSF antibodies (IgG). $" 190 \mathrm{~min}$ after challenge, challenge: $700 \mathrm{mg} / \mathrm{kg} \mathrm{GalN}$ plus $5 \mu \mathrm{g} / \mathrm{kg}$ LPS i.p. Mean values \pm SEM. ${ }^{1} P \leq 0.05$ vs. GalN/LPS alone. 


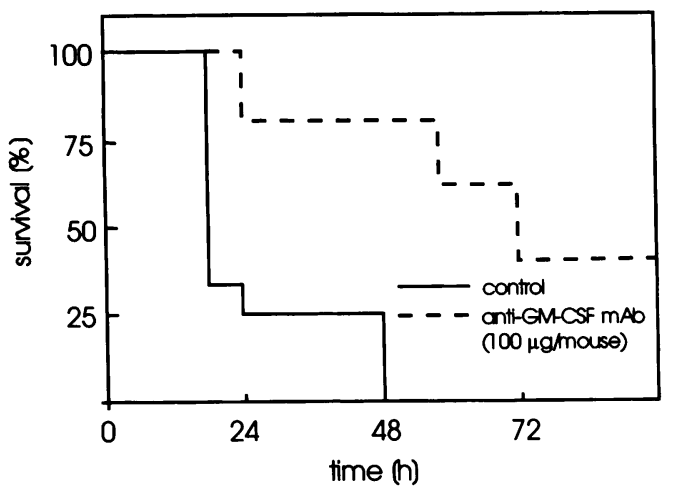

Figure 4. Protection of mice against lethal LPS challenge by a neutralizing anti-GM-CSF monoclonal antibody. GM-CSF mAb was administered i.v. in a volume of $300 \mu 10 \mathrm{~min}$ before lethal LPS challenge $(5 \mathrm{mg} / \mathrm{kg})$ i.p. $1.5 \mathrm{~h}$ after challenge, blood was withdrawn for determination of TNF (see Results). Mortality was monitored over time. $n=6$ for the control group and $n=5$ for the passively immunized group. The pretreatment significantly prolonged survival time $(P<0.05)$.

the eight GM-CSF-specific colonies identified in the soft agar assay (Table III) correspond to the detection limit of $5 \mathrm{pg} / \mathrm{ml}$ of the GM-CSF ELISA used in the time course experiments (Fig. 3). Other investigators have already reported that in humans no GM-CSF could be detected by ELISA after injection of small amounts of LPS (36). Therefore, circulating GM-CSF may only inaccurately reflect local concentrations of this cytokine, a concept that has been recently described as the 'tip of the iceberg' (37).

It is important to note that the initial TNF and GM-CSF release into serum occurred nearly simultaneously $30 \mathrm{~min}$ after LPS administration (Fig. 3) (33). These kinetics and the fact that GM-CSF administration even $30 \mathrm{~min}$ after LPS challenge could enhance TNF production in vivo (Table I) suggest that endogenous GM-CSF may modulate TNF formation or release. This is corroborated further by our finding that administration of GM-CSF to GalN/TNF $\alpha$-challenged mice failed to exacerbate hepatotoxicity and the anti-GM-CSF antibody did not protect against GalN/TNF $\alpha$ (Table III).

IL-1 is another cytokine which has been implicated in the pathogenesis of septic shock (38). Therefore, it was interesting to study whether GM-CSF would also enhance LPS-induced IL-1 production. However, because mouse serum was cytotoxic towards the cells used in the IL-1 bioassay, we were not able to determine IL-1 in vivo. To study the priming by GMCSF on LPS-induced IL-1 production, we chose two different approaches: $(a)$ we isolated spleen cells from mice challenged with LPS in vivo and measured the spontaneous IL-1 production of these cells after $20 \mathrm{~h}$ in culture; or $(b)$ we prepared bone marrow cells and stimulated these cells in vitro with LPS. In either case LPS stimulated measurable IL-1 release that was further enhanced by pretreatment or preincubation with GMCSF. Kinetic data obtained in vivo in mice showed that GMCSF (this study, 39) and IL-1 production (40) both reached maximum levels $2 \mathrm{~h}$ after LPS injection. These results indicate that IL-1 release occurs with a time course also likely to be modulated by GM-CSF.

Besides the action on TNF and IL-1 production, GM-CSF also seems to affect circulating IL-6. This cytokine has also been associated with sepsis (41) as a reliable marker of mortal- ity in experimental endotoxic shock in mice (42) and as a negative prognostic parameter for the severity of sepsis in humans (43). Our observation that in mice pretreatment with anti-GM-CSF antibody caused resistance towards lethal LPS challenge, associated with reduced serum levels of IL-6, while GM-CSF pretreatment augmented IL- 6 concentrations before subtoxic LPS challenge, confirm those conclusions drawn by others in different experimental settings. These in vivo data are also related to the report that GM-CSF, besides TNF $\alpha$ and LPS, induced considerable amounts of IL-6 from human polymorphonuclear leukocytes (10). However, we cannot decide whether the attenuated IL- 6 release in the anti-GM-CSF mAbtreated animals is caused directly by suppression of GM-CSF bioactivity or whether it is a consequence of reduced TNF production. These questions will be objects of further examination.

In the inflammatory response, both pro- as well as anti-inflammatory cytokines are known: TNF $(23)$, IL-1 $(44,45)$, and $\operatorname{IFN} \gamma(46,47)$ are able to aggravate LPS-induced shock or the fatal outcome of infectious diseases, whereas G-CSF (21), IL-4 (48), or IL-10 (49) are thought to represent factors terminating acute inflammatory processes. The interpretation of this study places GM-CSF in the role of a potentiator of the early stage of sepsis because it enhances the LPS-induced release of mediators such as TNF and IL-1 at a time of endogenous overstimulation of the nonspecific immune system. The reservation has to be acknowledged that this statement relates to the stage reflected in the animal model used here and does not exclude beneficial effects of so called proinflammatory cytokines if given at the appropriate time point. Nevertheless, our findings are of considerable practical interest for human therapy and may provide an explanation for some of the observed undesirable side reactions of clinically used GM-CSF, such as fever, chills, anorexia, weight loss, and pleural or pericardial inflammation (50). For instance, patients with neutropenia after chemotherapy were reported to have elevated serum levels of TNF $\alpha$ during GM-CSF therapy (51). In a study reported by Bar et al. 2 out of 14 cancer patients who received GM-CSF died of sepsis compared with 0 out of 12 patients treated with chemotherapy alone (52). A summary on the unfavorable effects of GM-CSF during treatment of cancer patients is given in references 15 and 52 . The doses applied clinically, i.e., up to 60 $\mu \mathrm{g} / \mathrm{kg}$ GM-CSF daily $(15,53)$, are comparable with the dose $(50 \mu \mathrm{g} / \mathrm{kg})$ used in our experiments. We conclude that the animal study reported here may help to explain some of the clinical observations and seems suitable to contribute a mechanistic interpretation of the aggravation of sepsis by GM-CSF treatment.

\section{Acknowledgments}

We are indebted to Dr. F. W. Seiler, Behring-Werke, Marburg/Lahn, Germany, for providing murine GM-CSF. We wish to acknowledge the help of Dr. H-U Beuscher, University of Erlangen, Germany, who provided anti-mouse IL- $1 \alpha$ antiserum.

This work was supported by the Deutsche Forschungsgemeinschaft, SFB 156, Grant We 686/14-1 within the Sonderforschungsbereich 156 .

\section{References}

1. Burgess, A. W., and D. Metcalf. 1980. The nature and action of granulocyte-macrophage colony stimulating factors. Blood. 56:947-958. 
2. Rapoport, A. P., C. N. Abboud, and J. F. DiPersio. 1992. Granulocyte-macrophage colony-stimulating factor (GM-CSF) and granulocyte colony-stimulating factor (G-CSF): receptor biology, signal transduction, and neutrophil activation. Blood Rev. 6:43-57.

3. Sullivan, R., J. D. Griffin, E. R. Simons, A. I. Schafer, T. Meshulam, J. P. Fredette, A. K. Maas, A.-S. Gadenne, J. L. Leavitt, and D. A. Melnick. 1987. Effects of recombinant human granulocyte and macrophage colony stimulating factors on signal transduction pathways in human granulocytes. J. Immunol. 139:3422-3430.

4. DiPersio, J. F., P. Billing, R. Williams, and J. C. Gasson. 1988. Human granulocyte-macrophage colony stimulating factor and other cytokines prime human neutrophils for enhanced arachidonic acid release and leukotriene $B_{4}$ synthesis. J. Immunol. 140:4315-4322.

5. Arnout, M. A., E. A. Wang, S. C. Clark, and C. A. Sieff. 1986. Human recombinant granulocyte-macrophage colony-stimulating factor increases cellto-cell adhesion and surface expression of adhesion-promoting surface glycoproteins on mature granulocytes. J. Clin. Invest. 78:597-601.

6. Socinski, M. A., S. A. Cannistra, R. Sullivan, A. Elias, K. Antman, L. Schnipper, and J. D. Griffin. 1988. Human granulocyte-macrophage colony stimulating factor induces expression of the CD11b surface adhesion molecule on granulocytes in vivo. Blood. 72:691-697.

7. Griffin, J. D., O. Spertini, T. J. Ernst, M. P. Belvin, H. B. Levine, Y. Kanakura, and T. F. Tedder. 1990. Granulocyte-macrophage colony stimulating factor and other cytokines regulate surface expression of the leukocyte adhesion molecule-1 on human neutrophils, monocytes, and their precursors. J. Immunol. 145:576-584.

8. Fischer, H. G., S. Frosch, K. Reske, and A. B. Reske-Kunz. 1988. Granulocyte-macrophage colony-stimulating factor activates macrophages derived from bone marrow cultures to synthesis of MHC class II molecules and to augmented antigen presentation function. J. Immunol. 141:3882-3888.

9. Lindemann, A., D. Riedel, W. Oster, S. C. Meurer, D. Blohm, R. H. Mertelsmann, and F. Herrmann. 1988. Granulocyte/macrophage colony-stimulating factor induces interleukin 1 production by human polymorphonuclear neutrophils. J. Immunol. 140:837-839.

10. Cicco, N. A., A. Lindemann, J. Content, P. Vandenbussche, M. Lübbert, J. Gauss, R. Mertelsmann, and F. Herrmann. 1990. Inducible production of interleukin- 6 by human polymorphonuclear neutrophils: role of granulocyte-macrophage colony-stimulating factor and tumor necrosis factor-alpha. Blood. 75:2049-2052.

11. Lindemann, A., D. Riedel, W. Oster, T. Loems, H. W. Ziegler-Heitbrock, R. Mertelsmann, and F. Herrmann. 1989. Granulocyte-macrophage colony-stimulating factor induces cytokine secretion by human polymorphonuclear leukocytes. J. Clin. Invest. 83:1308-1312.

12. Oster, W., A. Lindemann, R. Mertelsmann, and F. Herrmann. 1989. Granulocyte-macrophage colony-stimulating factor (CSF) and multilineage CSF recruit human monocytes to express granulocyte CSF. Blood. 73:64-67.

13. Morstyn, G., G. J. Lieschke, W. Sheridan, J. Layton, and J. Cebon. 1989. Pharmacology of the colony-stimulating factors. TIPS (Trends Pharmacol. Sci.). 10:154-159.

14. Whetton, A. D. 1990. The biology and clinical potential of growth factors that regulate myeloid cell production. TIPS (Trends Pharmacol. Sci.). 11:285289.

15. Moore, M. A. 1991. The clinical use of colony stimulating factors. Annu. Rev. Immunol. 9:159-191.

16. Metcalf, D. 1971. Acute antigen-induced elevation of serum colony stimulating factor (CSF) levels. Immunology. 21:427-436.

17. Seelentag, W. K., J. J. Mermod, R. Montesano, and P. Vassalli. 1987. Additive effects of interleukin 1 and tumor necrosis factor-alpha on the accumulation of the three granulocyte and macrophage colony-stimulating factor mRNAs in human endothelial cells. EMBO (Eur. Mol. Biol. Organ.) J. 6:22612265.

18. Koeffler, H. P., J. Gasson, and A. Tobler. 1988. Transcriptional and post-transcriptional modulation of myeloid colony-stimulating factor expression by tumor necrosis factor and other agents. Mol. Cell. Biol. 8:3432-3438.

19. Cannistra, S. A., E. Vellenga, P. Groshek, A. Rambaldi, and J. D. Griffin 1988. Human GM-CSF and IL-3 stimulate monocyte cytotoxicity through a TNF-dependent mechanism. Blood. 71:672-676.

20. Cohen, L., B. David, and J.-M. Cavaillon. 1991. Interleukin-3 enhances cytokine production by LPS-stimulated macrophages. Immunol. Lett. 28:121126.

21. Görgen, I., T. Hartung, M. Leist, M. Niehörster, G. Tiegs, S. Uhlig, F. Weitzel, and A. Wendel. 1992. Granulocyte colony-stimulating factor treatment protects rodents against lipopolysaccharide-induced toxicity via suppression of systemic tumor necrosis factor- $\alpha$. J. Immunol. 149:918-924.

22. Wendel, A. 1990. Biochemical pharmacology of inflammatory liver injury in mice. Methods Enzymol. 186:675-680.

23. Beutler, B., I. W. Milsark, and A. C. Cerami. 1985. Passive immunization against cachectin/tumor necrosis factor protects mice from lethal effect of endotoxin. Science (Wash. DC). 229:869-871.

24. Tiegs, G., M. Niehörster, and A. Wendel. 1990. Leukocyte alterations do not account for hepatitis induced by endotoxin or TNF $\alpha$ in galactosamine-sensitized mice. Biochem. Pharmacol. 40:1317-1322.

25. Decker, K., D. Keppler, J. Rudigier, and W. Domschke. 1971. Cell damage by trapping of biosynthetic intermediates. The role of uracil nucleotides in experimental hepatitis. Hoppe-Seyler's Z. Physiol. Chem. 352:412-418.

26. Galanos, C., M. A. Freudenberg, and W. Reutter. 1979. Galactosamineinduced sensitization to the lethal effects of endotoxin. Proc. Natl. Acad. Sci. USA. 76:5939-5943.

27. Deitch, E. A. 1992. Multiple organ failure. Ann. Surg. 216:117-194.

28. Nolan, J. P. 1989. Intestinal endotoxins as mediators of hepatic injuryan idea whose time has come again. Hepatology. 10:887-891.

29. Hopkins, S. J., and M. Humphreys. 1989. Simple, sensitive and specific bioassay of interleukin-1. J. Immunol. Methods. 120:271-276.

30. Espevik, T., and J. Nissen-Meyer. 1986. A highly sensitive cell line, WEHI 164 clone 13 , for measuring cytotoxic tumor necrosis factor from human monocytes. J. Immunol. Methods. 95:99-105.

31. Metcalf, D. 1984. Clonal culture of hemopoietic cells: techniques and applications. Elsevier Science Publishers B. V., Amsterdam.

32. Zar, J. H. 1984. Biostatistical analysis, 2nd edition. Prentice-Hall, NJ. 201 pp.

33. Wendel, A., M. Niehörster, and G. Tiegs. 1991. Leukotrienes, oxygen radicals, and cytokines in septicemic mice, in: 42. Colloquium Mosbach 1991; Molecular Aspects of Inflammation. Springer-Verlag, Heidelberg. 269-276.

34. Lehmann, V., M. A. Freudenberg, and C. Galanos. 1987. Lethal toxicity of lipopolysaccharide and tumor necrosis factor in normal and D-galactosaminetreated mice. J. Exp. Med. 165:657-663.

35. Tiegs, G., M. Wolter, and A. Wendel. 1989. Tumor necrosis factor is a terminal mediator in galactosamine/endotoxin-induced hepatitis in mice. Biochem. Pharmacol. 38:627-631.

36. Granowitz, E. V., R. Porat, S. F. Orencole, M. V. Callahan, E. A. Lynch, S. M. Wolff, and C. A. Dinarello. 1992. Granulocyte-macrophage colony stimulating factor synthesis during experimental endotoxemia in humans. J. Infect. Dis. 166:1204-1205.

37. Cavaillon, J. M., C. Munoz, C. Fitting, B. Misset, and J. Carlet. 1992. Circulating Cytokines-The Tip of the Iceberg. Circ. Shock. 38:145-152.

38. Dinarello, C. A. 1992. Role of IL-1 in infection. Immunol. Rev. 127:1 1946.

39. Piquet-Pellorce, C., and M. Dy. 1991. Effect of lipopolysaccharides on histamine synthesis by hematopoetic cells. Cell. Immunol. 135:360-371.

40. Chensue, S. W., M. D. Terebuh, D. G. Remick, W. E. Scales, and S. L. Kunkel. 1991. In vivo biologic and immunohistochemical analysis of interleukin1 alpha, beta and tumor necrosis factor during experimental endotoxemia. Am. J. Pathol. 138:395-402.

41. Bone, C. 1991. The pathogenesis of septic shock. Ann. Intern. Med 115:457-469.

42. Kelly, N. M., and A. S. Cross. 1992. Interleukin-6 is a better marker of lethality than tumor necrosis factor in endotoxin treated mice. FEMS (Fed. Eur. Microbiol. Soc.) Microbiol. Immunol. 89:317-322.

43. Damas, P., L. Ledoux, M. Nys, Y. Vrindts, D. Degroote, P. Franchimont, and M. Lamy. 1992. Cytokine serum level during severe sepsis in humans. IL-6 as a marker of severity. Ann. Surg. 215:356-362.

44. Wakabayashi, G., J. A. Gelfand, J. F. Burke, R. C. Thompson, and C. A. Dinarello. 1991. A specific receptor antagonist for interleukin 1 prevents Escherichia coli-induced shock in rabbits. FASEB (Fed. Am. Soc. Exp. Biol.) J. 5:338343.

45. Alexander, H. R., G. M. Doherty, C. M. Buresh, D. J. Venzon, and J. A Norton. 1991. A recombinant human receptor antagonist to interleukin $1 \mathrm{im}-$ proves survival after lethal endotoxemia in mice. J. Exp. Med. 173:1029-1032.

46. Freudenberg, M. A., Y. Kumazawa, S. Meding, J. Langhorne, and C. Galanos. 1991. Gamma interferon production in endotoxin-responder and -nonresponder mice during infection. Infect. Immun. 59:3484-3491.

47. Katschinski, T., C. Galanos, A. Coumbos, and M. A. Freudenberg. 1992. Gamma interferon mediates Propionibacterium acnes-induced hypersensitivity to lipopolysaccharide in mice. Infect. Immun. 60:1994-2001.

48. Banchereau, J. 1991. Interleukin-4. In The Cytokine Handbook. A. Thomas, editor. Academic Press Ltd, London. 119-148.

49. Zlotnik, A., and K. W. Moore. 1991. Interleukin 10. Cytokines. 3:366371.

50. Lieschke, G. J., and A. W. Burgess. 1992. Drug Therapy. Granulocyte colony-stimulating factor and granulocyte-macrophage colony-stimulating factor. Part I. N. Engl. J. Med. 327:28-35.

51. Stehle, B., C. Weiss, A. D. Ho, and W. Hunstein. 1990. Serum levels of tumor necrosis factor $\alpha$ in patients treated with granulocyte-macrophage colonystimulating factor. Blood. 75:1895-1896.

52. Bar, M. H., F. R. Aronson, K. H. Antman, A. M. Elias, S. A. Cannistra, E. Frei, L. E. Schnipper, and J. D. Griffin. 1989. Recombinant human GM-CSF in myelosuppression of chemotherapy. $N$. Engl. J. Med. 320:939-940.

53. Lieschke, G. J., and A. W. Burgess. 1992. Drug Therapy. Granulocyte colony-stimulating factor and granulocyte-macrophage colony-stimulating factor. Part II. N. Engl. J. Med. 327:99-106. 